REFERENCES

Bird, H. R., Rubin, M. \& Groschke, A. C. (1948). 7. biol. Chem. r74, 6 I I.

Coates, M. E., Ford, J. E., Harrison, G. F., Kon, S. K., Porter, J. W. G., Cuthbertson, W. F. J. \& Pegler, H. F. (r951). Biochem. F. 49, lxvii.

Coates, M. E., Harrison, G. F. \& Kon, S. K. (1951). Analyst, 76, 146.

Dam, H. (1934). Nature, Lond., 133, 909.

Davies, M. K. (1958). A study of certain factors affecting the sensitivity of chicks to vitamin deficiencies. Ph.D. Thesis, University of Reading.

Eijkman, C. (1897). Virchows Arch. 148, 523.

Fell, H. B. \& Mellanby, E. (1952). F. Physiol, xx6, 320.

Fell, H. B. \& Mellanby, E. (1953). F. Physiol. rx9, 470.

Fell, H. B., Mellanby, E. \& Pelc, S. R. (1954). Brit. med. F. ii, 6 I r.

Fell, H. B., Mellanby, E. \& Pelc, S. R. (r956). F. Physiol. r34, r79.

Ford, J. E., Kon, S. K. \& Porter, J. W. G. (1951). Biochem. $\mathscr{F}$. 50, ix.

Grant, W. C. \& Fahrenbach, M. J. (1959). Proc. Soc. exp. Biol., N.Y., roo, z5o.

International Congress for Microbiology, Stockholm. (1958). Recent Progress in Microbiology. Symposium 5 , pp. $259-368$.

Kritchevsky, D., Grant, W. C., Fahrenbach, M. J., Riccardi, B. A. \& McCandless, R. F. J. (1958). Arch. Biochem. Biophys. 75, 142.

Kritchevsky, D., Kolman, R. R., Guttmacher, R. M. \& Forbes, M. (I959). Arch. Biochem. Biophys. 85,444 .

Moore, J. H. \& Doran, B. M. (1961). Biochim. biophys. Acta, 49, 6 I 7.

Porter, J. W. G. (1956). Ist European Symposium on Vitamin $\mathrm{B}_{12}$ and Intrinsic Factor, Hamburg, pp. 43-55. Stuttgart: Ferdinand Enke Verlag.

Rickes, E. L., Brink, N. G., Koniuszy, F. R., Wood, T. R. \& Folkers, K. (1948). Science, ro7, 396.

Rubin, M., Groschke, A. C. \& Bird, H. R. (1947). Proc. Soc. exp. Biol, N.Y., 66, 36.

Smith, E. L. (1948). Nature, Lond., 16r, 638.

Waddell, J. (1934). F. biol. Chem. 105, 7 I 1 .

Williams, H. H., Erickson, B. N., Bernstein, S., Hummel, F. C. \& Macy, I. G. (I937). F. biol. Chem. I 18,599 .

\title{
Some basic mechanisms of hunger and satiety
}

By S. Lepkovsky, S. Feldman and I. Sharon, Department of Poultry Husbandry, University of California, Berkeley, California, U.S.A.

\section{Introduction}

Feeding and cessation of feeding are essential features in all living systems. 'All animals that have been studied, those without alimentary tracts as well as those which have, recognize food, spurn food when it is superabundant and put forth extra efforts to get it when it is rare. Hence, whatever be the machinery that may fix the pattern of priorities in rats, comparable patterns seem to be endowments of all animals whether or not they possess specialized neuromuscular or alimentary systems' (Adolph, 1947).

To survive, animals must not only eat but must eat a nutritionally adequate diet which they must select from the foods that are available in the external environment. Their choice of food is guided by the need for many nutrients that have been depleted in their bodies. The depletion of energy is expressed as hunger. 'Specific hungers' exist for many specific nutrients that have been depleted (Scott, I948; Richter, 1942-3). Apparently deficits of many nutrients are not expressed as 'specific hunger' (Scott, 1948) and presumably their ingestion is left to chance.

2I (I) 6 
For everything that happens in living systems there must be a mechanism. An understanding of nutrition is not possible without an understanding of the mechanisms that make it possible. At present we do not know how many such mechanisms exist, but we do know of a considerable number.

\section{Transfer of the nutrients of the food from the external environment to the cell}

In nutrition we are in reality feeding the cells of the body and they are aquatic organisms, living in a medium, the extracellular fluid, which is frequently referred to as the internal environment. The composition of this medium is fixed, presumably determined by the composition of the archaic sea where life began and which has remained as a determinant of the conditions of life. Any great departure from the 'fixed' composition of the extracellular fluid of the animal results in profound disturbances and may end in death (Cannon, r932).

The transfer of the nutrients of food from the external environment to the cell must be effected without changing the composition of the internal environment. Nutrients ingested in excess of those needed must be disposed of, and special mechanisms exist for this purpose.

\section{Barriers and their function in the protection of the internal environment}

The mouth. The mouth is the first barrier that protects the internal environment. Careful selection of food is made at the mouth to supply not only the nutrients needed by the cells but also to supply them in the best possible balance permitted by the available food supply.

The pyloric sphincter. The food passes out of the stomach into the intestine slowly and at a rate that makes possible digestion and reduction of the food into nutrients that can be used by the cells. Toxic compounds ingested with the food enter the system slowly so that they can be excreted or detoxified.

The intestine. Regulation of the absorption of some nutrients occurs in the intestine, especially that of calcium and iron.

Elimination of absorbed surpluses. Surpluses are largely eliminated by the kidney. Some surpluses are re-excreted into the intestine where they are eliminated with the faeces. Energy that is not expended is stored as fat.

Entry into the cell. After the nutrients reach the cells, they still cannot be considered nutrients until they have gained entry into the cell. To do so they must get through the cell membrane.

\section{Hunger and appetite}

Definitions. After a fast, the tissues of animals become depleted of nutrients and the organism develops an awareness of this condition through a sensation or state of mind which is expressed as hunger; this may be looked upon as an expression of need which can be met by eating. Human beings, much more so than animals, will eat without any need for food or without being hungry. This has been referred to as a 'privilege of the human species to eat without hunger and to drink without thirst' (Brillat-Savarin, 1948). The value of this privilege is debatable. 
There is so much confusion in the use of the terms hunger and appetite that it has been suggested that these terms be banished 'for the sake of linguistic peace' (Jannowitz, I958). It is suggested that we look upon hunger as 'the physiologic state resulting from deficits of nutrients which manifests itself in a disagreeable complex of sensations including epigastric hunger pang, and the behaviouristically activated feeding reflexes and increased motor activity' (Jannowitz, 1958). Appetite may be defined simply as the desire for food (Jannowitz, 1958). Hamburger (1960) defined hunger as a demand for relief from pain and an unpleasant condition. More simply stated, hunger is a painful disease curable by food. Food is the oldest tranquilizer known (Brobeck, r959). Appetite seeks pleasure and satisfaction. Hunger may be referred to the primitive brain or the hypothalamus; appetite refers to the higher cortical centres where reside thought, consciousness and memory (Anand, 1960).

Hunger and thirst are two of the most powerful motivational drives known. The terms are used to express intense desires, 'appetite for wealth', 'hunger for power', 'thirst for vengeance', 'insatiable desire for riches'.

The reliability of hunger as an expression of nutrient deficits cannot always be depended upon, as a prolonged fast is accompanied by loss of hunger (HelwegLarsen, Hoffmeyer, Thaysen, Thygesen \& Wolff, 1952).

Regulation of calorie intake. After the period of growth has ceased, the energy stores of the body, and more specifically the fat stores, remain relatively constant (Grossman, 1958). 'This constancy is achieved mainly by regulating energy intakethat is, food intake-so that it is essentially equal to energy expenditure, thus leaving no surplus or deficit to cause changes in stored energy' (Grossman, 1958). Energy exchange was seen as the regulation of four factors: food intake, heat loss, energy stored and work output, the common denominator being energy (Brobeck, I948).

Regulation of other nutrients. Not only is the intake of energy regulated, but we must also assume that mechanisms exist to regulate the amount of water and other nutrients in the body. Some of the nutrients regulated are known from their regulators; for example, the adrenal cortex regulates the excretion of sodium (Richter, 1936), the parathyroid glands regulate that of phosphorus (Shelling, I932), and the posterior pituitary gland controls the tubular reabsorption of water (Gaunt \& Birnie, r95I). The levels of many other nutrients in the body fluids are regulated, such as those of potassium, calcium, glucose, chlorine, bicarbonate and carbon dioxide.

\section{Nutrition : alternate fasting and feeding}

During eating, nutrients are stored in the body. 'Those serving as sources of energy are stored in largest amounts, mostly as fat in the adipose tissue, which is elastic and may enlarge into a major fraction of the body. During fasting, nutrients are consumed to maintain bodily functions, for which energy is needed and comes from the tissues of the animal, mostly from fat of the adipose tissue. Before the animal can use it, the fat must be mobilized from the adipose tissues. This process is made possible by mechanisms controlled through the action of the sympathetic nervous system, the 
growth and adrenocorticotrophic hormones of the anterior pituitary and the medullary and cortical hormones of the adrenal. Each of these mechanisms requires the participation of specific enzymes, and malfunction of one enzyme, such as the lipase needed to hydrolyse the glycerides to fatty acids, could well impair the mobilization of fat from the adipose tissue. If the fat needed to supply the energy for the cells of the body is unavailable, they go into a state of undernutrition which would be expressed as hunger.

A number of processes go on in animals during fasting and eating. All these processes represent mechanisms due to the activity of specific enzymes, all of them acting simultaneously in an integrated manner to make normal nutrition possible. Any impairment in any one of these numerous enzyme systems that participate in nutritional processes could cause nutritional disturbances. We are slowly getting a deeper insight into the complex biochemistry that confronts the nutritional investigators of tomorrow.

\section{Biochemical mechanisms during fasting}

During fasting the level of blood glucose must be maintained to enable the brain to function, since glucose is its only known source of energy. Many mechanisms participate in the maintenance of the glucose level of the blood of the fasting animal (Engel, 1952).

Glucose utilization. Glucose utilization is inhibited, through inhibition of the conversion of glucose into fat, glycogen and protein, and impairment of the oxidation of glucose.

Fat utilization. The utilization of fat is increased, and thus the loss of carbohydrate as a source of energy due to the inhibition of the utilization of glucose is balanced. The mobilization of fat from the adipose tissues is increased and the fat is transported to the other tissues as non-esterified fatty acids (Dole, I958). The oxidation of fat is increased (Engel, 1952).

Synthesis of new glucose. Although the utilization of glucose is inhibited, some glucose is continually used up and some source of glucose must be found. Glycogen is used to meet the immediate demand for glucose, and later more glucose is made available from body protein through gluconeogenesis; through this mechanism the blood glucose may be maintained during long periods of fasting (Engel, 1952).

Regulation of blood glucose. The blood glucose level is maintained largely through the opposing action of the pituitary and pancreas (Engel, r952).

\section{Hunger complex : expression of nervous system during fasting}

The biochemical state of the fasting tissues is communicated to the nervous system where it is expressed as a sensation of hunger. The expression of the nervous system of animals during fasting can be deduced from the behaviour of the animal. The fasting human being has added much information on the expression of the nervous system during fasting since he can describe sensations, motivations and other feelings. 
Hyperirritability. This is a universal expression of the fasting animal (Brobeck, 1959). In animals it is expressed in heightened activity. This is true for the protozoa (Carlson, 1916) and decerebrate animals (Brobeck, 1959). In rats (Richter, 1922) and mice (Hollifield \& Parson, 1957) it is measured as running activity, and in man it has been observed in the knee jerk (Brobeck, 1959) and in the olfactory tissue (F. Goezl, personal communication), e.g. where it has been expressed as a keener sense for the odour of coffee.

Other expressions of hunger. In human beings other expressions of hunger have been observed. The hungry man has an exaggerated interest in food, talking about food all day and dreaming about it at night (Englander, 1943). He will beg for food, steal food and eat inedible material (Quigley, I955). He develops an ugly personality so that neither man nor beast can live with him, and he has disagreeable complex sensations and tormenting afflictions demanding relief.

\section{Measurement of hunger}

In the past, hunger was determined by measuring the food intake. This measured mainly the energy exchange of the animal. Hunger contractions have also been used as a measure of hunger (Carlson, r9 I6). Other measurements of hunger have been introduced (Miller, 1957). One is motivation, which has been measured by the willingness of animals to work for food, e.g. by working various devices in specially constructed cages, or by the use of quinine to discourage the animal from eating food. Another measure has been the use of food to reduce the strength of hunger as a means to produce learning. 'If food injected directly into the stomach produces a prompt reduction in the strength of hunger, the drive-reduction hypothesis of reinforcement demands that such injection should serve as a reward to produce learning' (Miller, r957).

\section{Measurement of deficits of specific nutrients}

Water deficit leads to a sensation of thirst. Deficit of fat leads to no such sensations as hunger or thirst. Yet the term 'fat-hunger' is well known. Fat deficit is expressed as a craving for fat and as the 'delicious taste' that fat has for people during the period of its deficiency. After repletion, fat loses its delicious taste and if ingested in excess becomes nauseous (I. I. Ritter, personal communication). Hunger for thiamine, riboflavin, pyridoxine and other nutrients is known to occur in rats, but there is little information about it or on how to measure such hunger (Scott, I948).

\section{Responses to the hunger complex}

Food-seeking behaviour. The first essential for finding food is locomotion. There are no restaurants in nature and animals must find their food. Written records of early civilizations indicate that human beings fared similarly to animals in the difficult task of obtaining enough food. Famine was the most common disease of early man because of the difficulty in producing food and the absence of facilities to store it. 
Food-seeking behaviour also calls for searching, exploration and examination. This leads to discrimination and to the choice of food which meets the needs of the animal-a nutritionally adequate diet (Brobeck, 1959). Pursuit and fighting may be included in food-seeking behaviour (Brobeck, 1959) since frequently the available food is on the hoof and the animal must be caught before it can serve as food. Fighting is frequently necessary since no animal willingly serves as food for another. Hence fighting and fleeing are part of the basic urge to live.

Logically, hoarding is part of food-seeking behaviour but is little understood.

Acceptability. After food has been found it must be eaten, since 'food is not a food until it is eaten'. For many animals acceptability is determined almost wholly by the nutritional value of the food, but in human beings or insects (Fraenkel, I958) there is little relation between the nutritional value of food and its acceptability. Other factors such as flavour and conditioning may be decisive factors in determining acceptability.

In addition to initial acceptability, we must also deal with continuing acceptability; the opposite is monotony. Why do some foods become monotonous quickly and others hardly ever evoke monotony?

\section{Eating}

Recognition and discrimination. Somehow the animal has to differentiate between food and other objects in the environment. After recognizing food, the animal has to choose an adequate diet (Richter, I942-3). This is made possible by the sensory properties of food, the flavour, odour, colour and texture of the food. These act as sensory stimuli which are perceived by the acceptors in the head, the taste buds and the nerve endings in the mouth and pharynx, the eyes and ears (Von Buddenbrock, I958). These stimuli are communicated to the central nervous system over the nerve tracts as electrical stimuli, where they are perceived and integrated with information from the body, with the result that food is recognized and judged acceptable or not as the case may be; the food is then either eaten or rejected.

The act of eating. In the act of eating, receptors are activated in the chewing muscles (proprioceptors), tongue and teeth. From receptors in these tissues stimuli go to the brain over the nerve tracts (Langley \& Cheraskin, 1956). The act of chewing is very important as a source of sensory stimuli and may be as important as the division of the food for proper nutrition.

\section{Response to eating - satiety complex}

Cessation of eating. The animal stops eating and experiences satiety before the food has been digested and absorbed and before the metabolic debt incurred during the fast has been paid off (Grossman, 1958). How does the body know that the nutrient deficit has been made up by eating? Yet the animal knows. A dog left without food for $24 \mathrm{~h}$ will eat in Io min the amount of food needed to make up its calorie deficit. A mechanism exists to enable the animal to do this. It involves communication from the mouth and stomach. Two types of sensory stimuli from the mouth go to the 
brain, one from the food and the other from the receptors in the teeth, chewing muscles and muscles of the tongue. Secondly, distention of the stomach activates the stretch receptors in its wall and stimuli go to the brain through the vagus nerve. The information coming to the brain from the mouth and the stomach is integrated and the animal responds with cessation of eating. This seems true also for the blowfly (Dethier \& Bodenstein, 1958) as well as for the human being. We do not know whether this is the whole answer.

Pleasure from eating. An indispensible component of satiety is the pleasure experienced from eating. It is especially important for human beings. In all animals eating changes the state of hunger to a state of satiety. Hyperirritability is replaced by relaxation, the urge for locomotion is replaced by a desire for rest and sleep. The ugly personality is replaced by a pleasant one.

\section{Biochemistry of the fed animal}

The biochemistry of the fasting animal is replaced by that of the fed animal. The utilization of glucose is no longer inhibited. Instead its utilization is accelerated and glucose is rapidly converted into fat, glycogen and protein. Gluconeogenesis is inhibited. The mobilization of fat is inhibited. Instead, fat is deposited in the tissues of the fed animal. The utilization of fat is reduced and simultaneously the oxidation of carbohydrate is increased. All these processes are stimulated by insulin.

\section{Regulation of biochemical reactions in the fasting and fed animal}

In the fasting animal, the anterior pituitary gland is activated and the insulin mechanism is inhibited. The fasting condition resembles in many respects that of a depancreatized animal. In the fed animal, the insulin mechanism of the pancreas is activated and the pituitary gland is inhibited. It is suggested that the actions of the pituitary gland and of the pancreas are co-ordinated in the hypothalamus in these nutritional processes.

\section{Some implications in the chicken}

The nutritional processes discussed above go on in chickens just as in other animals. There may be differences in chickens in certain specific processes. For example, depancreatized chickens do not experience diabetes. Either the chicken has an extrapancreatic source of insulin or else it can carry on normal carbohydrate metabolism without insulin. The answer will come from appropriate investigations.

The hypothalamus of the chicken has been investigated for the presence of the feeding and satiety centres that have been shown to exist in other animals. In these studies it is necessary to remember that the hypothalamus contains representations or nuclei for appetite (hunger), satiety, water metabolism, reproduction, temperature regulation, motor activity, and the emotions, all of them dynamically interrelated with each other and all of them affecting food intake (Brobeck, r959). These nuclei are anatomically contiguous with each other, so that it is difficult to obtain a single 
effect with a lesion. Aphagia has been produced in chickens (Feldman, Larsson, Dimick \& Lepkovsky, I957). They do not eat nor do they show any interest in food. They may be maintained indefinitely by introducing food into their crops mechanically. Some of these chickens are apparently normal. Some of them lose their ability to regulate their body temperature. In hot weather they do not show the behaviour of normal birds, such as panting to lose heat. Frequently they succumb in hot weather. Aphagic chickens also reduce their motor activity, become more placid and lose much of the hyperexcitability of White Leghorns. All the aphagic chickens (males) tested were normal sexually, since they possessed viable sperm capable of fertilizing hens that produced fertile eggs which hatched into normal chicks.

Hyperphagia was also produced in male chickens (Lepkovsky and others, unpublished). They ate in excess and became very fat. The most obese showed impairment in the release of the gonadotrophic hormones from the pituitary and took on the appearance of capons. Their combs shrank and their testes were atrophied. These birds also showed reduced motor activity and decreased excitability.

Other birds with lesions in the hypothalamus showed diabetes insipidus (Lepkovsky and others, unpublished work) indicating abnormal function of the posterior pituitary with decreased release of the antidiuretic hormone. Large volumes of urine were excreted, and some of the birds ceased laying, showing that the lesion impaired the function of the anterior pituitary also. Most of them continued to lay.

These sketchy experimental results point to the hypothalamus as a tissue with important biological activity which it exerts through other tissues such as the anterior and posterior pituitary. Moreover, food and water intake, temperature regulation and the emotions are functions that are related to the external environment. In a sense, therefore, the hypothalamus may be looked upon as the cross-roads between the environment and the internal biochemistry.

We wish to thank the National Institutes of Health, Bethesda, Md, for their support of our research work under grant A-1805. We wish to thank Dr Alan Greenwood for his co-operation and for the use of the facilities of the Poultry Research Centre, Edinburgh; the staff were most helpful in the preparation of this paper.

\section{REFERENCES}

Adolph, E. F. (г947). Amer. F. Physiol. r51, г го.

Anand, B. K. (1960). Amer. F. clin. Nutr. 8, 529.

Brillat-Savarin, J. A. (1948). The Physiology of Taste. A complete translation from the French. New York: Liveright Publishing Corp.

Brobeck, J. R. (I948). Yale F. Biol. Med. 2o, 545.

Brobeck, J. R. (I959). In Handbook of Physiology, Sect. ז, Neurophysiology, Vol. 2. [J. Field, H. W. Magown and V. E. Hall, editors.] Washington, D.C.: American Physiological Society.

Cannon, W. B. (1932). The Wisdom of the Body. New York: Norten.

Carlson, A. J. (1916). Control of Hunger in Health and Disease. Chicago: University Press.

Dethier, V. G. \& Bodenstein, C. V. (1958). Tierpsychol. 15, 129.

Dole, V. P. (1958). Arch. intern. Med. 101, ro05.

Engel, F. L. (1952). Bull. N.Y. Acad. Med. 29, I75.

Englander, D. A. (r943). Liberty Magazine, 7 July.

Feldman, S. E., Larsson, S., Dimick, M. K. \& Lepkovsky, S. (1957). Amer. F. Physiol. 191, 259.

Fraenkel, G. (1958). Abstracts of Invitation Papers, Eighteenth Annual Meeting of the Entomological Society of $\mathcal{J a p a n , ~ H o k k a i d o ~ U n i v e r s i t y , ~ S a p p o r o , ~ J a p a n . ~}$ 
Gaunt, R. \& Birnie, J. H. (195 I). Hormones and Body Water. Springfield, Ill.: C. C. Thomas.

Grossman, M. I. (1958). Amer. F. dig. Dis. N.S. 3, 659 .

Hamburger, W. W. (1960). Amer. F. clin. Nutr. 8, 569 .

Helweg-Larsen, P., Hoffmeyer, J. K., Thaysen, E. H., Thygesen, P. \& Wolf, M. H. (r952). Acta med. scand. Suppl. 274, p. 174 .

Hollifield, G. \& Parson, W. (1957). J. clin. Invest. 36, 1638.

Jannowitz, H. D. (1958). Amer. F. Med. 25, 327.

Langley, L. L. \& Cheraskin, E. (1956). Physiological Foundations of Dental Practice. St. Louis : C. V. Mosby Co.

Miller, N. E. (1957). Science, 126, 1271.

Quigley, J. P. (1955). Ann. N.Y. Acad. Sci.63,6.

Richter, C. P. (1922). Comp. Psychol. Monogr. I, no. 2, p. 55.

Richter, C. P. (1936). Amer. F. Physiol. 115, I55.

Richter, C. P. (1942-3). Harvey Lect. 38, 63.

Scott, E. M. (1948). Trans. Amer. Ass. Cereal Chem. 6, 126.

Shelling, D. H. (1932). F. biol. Chem. 96, 195.

Von Buddenbrock, W. (1958). The Senses. Ann Arbor: University of Michigan Press.

\section{Antibiotics and other growth-promoting substances}

\section{By J. H. Taylor, Agricultural Division, Cyanamid of Great Britain Limited, London, W.C.2}

It has become accepted practice to include in the diet of poultry and other animals a range of additives which have no apparent direct nutritional value, but which, nevertheless, help to maintain or increase the level of animal production. Such supplements are usually incorporated in the feed at a very low level and are given on a continuous or semi-continuous basis. The feed serves merely as a convenient vehicle, and sometimes subcutaneous implantation or addition to the drinking water is a possible alternative.

Non-nutritional feed additives may be classified into two groups:

(a) Those substances that prevent or reduce the incidence or severity of infectious disease. In this context the term 'disease' includes not only obvious clinical disease, but any detrimental modification of the microbial flora of the host animal which is reflected in reduced productivity. Such compounds produce no growth response in birds reared in a sterile environment and they normally remove a growth-depressing effect rather than produce a direct growth stimulation. This group includes antibacterial and antiprotozoal agents as exemplified by the antibiotics, the sulphonamides, the nitrofurans and a range of specific coccidiostats and histomonostats. Organic arsenical compounds may also fall largely within this group.

(b) Those substances that bring about changes in the metabolism of the animal, producing an increase in rate of growth or productivity. Such compounds show little or no antimicrobial activity and would be likely to produce a consistent growth stimulation in either a sterile or conventional environment. This group consists mainly of substances having hormonal activity; they are of considerably less practical importance at present than the antimicrobial agents. 